\title{
Aiding Activism? Humanitarianism's Impacts on Mobilized Syrian Refugees in Jordan
}

\author{
Rana B. Khoury \\ Northwestern University \\ rbkhoury@u.northwestern.edu
}

\begin{abstract}
A common narrative of the Syrian conflict suggests that it began with a grassroots uprising and devolved into a violent war between armed actors, leaving civilians to become victims or warriors. A more careful consideration of developments in and around Syria uncovers evidence of continued unarmed mobilization among civilians. Indeed, refugees in neighboring countries like Jordan are deeply engaged in humanitarian, developmental, and political endeavors. In this study, qualitative research and a unique survey together demonstrate that Syrians in Jordan have engaged in abundant activism on behalf of the Syrian cause. Still, the overwhelming militarism and humanitarianism that have characterized the Syrian crisis have had their impacts: activist organization is constricted and configured by security imperatives and, paradoxically, by the aid regime assisting civilians in the conflict. In turn, activism has evolved from grassroots mobilization to a formal and aid-based response to a humanitarian crisis.
\end{abstract}

\section{Keywords}

refugees - civil war - activism - humanitarianism - Syria - Jordan - respondent-driven sampling - aid

* This research was generously supported by the Council of American Overseas Research Centers and the Kellogg School of Management at Northwestern University. My gratitude is also owed to Ana Arjona, Laurie Brand, Laura Garcia, Marc Lynch, Wendy Pearlman, William Reno, Jason Seawright, and Alex Shakar. 
"What began as a peaceful uprising against Syria's President Bashar al-Assad six years ago became a full-scale civil war that has left more than 300,000 people dead, devastated the country and drawn in global powers."1 So begins an archetypal narrative of the Syrian conflict, in which force overwhelmed mass mobilization, and civilians became mere victims or armed warriors. Despite the dizzying truth of the violence, a more careful consideration of Syria's warscape - that place of transformative social processes in and around a warzone ${ }^{2}$ - uncovers evidence of continued unarmed mobilization among civilians. How has nonviolent mobilization in the Syrian warscape persisted, even in the shadow of the war and humanitarian crisis? And what does this activism look like years after the street protests that captured our early attention? Refugees in neighboring countries, and their civilian counterparts inside Syria, are deeply engaged in humanitarian, developmental, and political endeavors. They constitute part of a dense landscape of state and non-state actors involved in responding to developments in and around Syria, leading us to inquire further into how external actors - neighboring countries, donor governments, and inter- and non-governmental organizations-have affected the evolution of their activism. Organizing amid extremist groups and numerous other armed forces, activists have become extensively intertwined with external actors. Whither their mobilization?

To better understand the trajectories of civilian mobilization in and around Syria, this article focuses on one space within the warscape: neighboring Jordan. Analysis of quantitative and qualitative evidence demonstrates that Syrians in Jordan have engaged in activism - non-routine and nonviolent action carried out on behalf of a cause. ${ }^{3}$ These activities range from psychosocial support for fellow refugees to the development of institutions based in rebel-held territory inside Syria. Their activism is testament to the agency of unarmed actors in wartime, and challenges conceptions of refugees as victims or warriors. Still, it is shaped by the overwhelming militarism and humanitarianism associated with the Syrian crisis. Indeed, in Jordan, opportunities for activism have been constricted not only by security imperatives, but also

1 ввС News, “Why is there a war in Syria?", ввс News, April 7, 2017, http://www.bbc.com/news/ world-middle-east-35806229.

2 Stephen C. Lubkemann, Culture in Chaos: An Anthropology of the Social Condition in War (Chicago and London: University of Chicago Press, 2008). Nordstrom coined "war-scapes" to refer to the enmeshing of transnational and local concerns, actors, and interactions in the cultural construction of conflict. Carolyn Nordstrom, A Different Kind of War Story (Philadelphia: University of Pennsylvania Press, 1997).

3 Brian Martin, "Activism, Social and Political," in Encyclopedia of Activism and Social Justice, ed. Gary L. Anderson and Kathryn G. Herr (Thousand Oaks: SAGE Publications, Inc., 2007). 
by the humanitarian and developmental response aiding civilians caught in the warscape. In turn, activism has evolved from grassroots mobilization to a formal and financed response to a humanitarian crisis-a paradoxical (if unintended) outcome of outsiders' efforts to help those in need.

In the wake of multiple intrastate conflicts through the 1990s, analysts came to associate refugees with violence and the spread of civil wars. " "Refugee warriors" became parlance for rebels fighting from neighboring states, ${ }^{5}$ and scholars pointed the finger at host states and the international refugee regime for structuring opportunities for these violent outcomes. ${ }^{6}$ At the same time, states and the humanitarian system have been indicted for reinforcing refugees' disempowerment and political deprivation. ${ }^{7}$ Notwithstanding, scholarly case studies have increasingly identified refugees' enactment of agency and resistance, including activism, an outcome between violence and victimhood. Few quantitative studies capture this nonviolent outcome among individuals

4 Myron Weiner, "Bad Neighbors, Bad Neighborhoods: An Inquiry into the Causes of Refugee Flows," International Security 21, no. 1 (1996); Idean Salehyan, "The Externalities of Civil Strife: Refugees as a Source of International Conflict," American Journal of Political Science 52, no. 4 (2008).

5 Aristide R. Zolberg, Astri Surke, and Sergio Aguayo, Escape from Violence: Conflict and the Refugee Crisis in the Developing World (Oxford: Oxford University Press, 1989).

6 Howard Adelman, "The Use and Abuse of Refugees in Zaire," in Refugee Manipulation: War, Politics, and the Abuse of Human Suffering, ed. Stephen Stedman and Fred Tanner (Washington, DC: Brookings Institution Press, 2003); Stephen Stedman and Fred Tanner, "Refugees as Resources in War," ibid.; Sarah Kenyon Lischer, Dangerous Sanctuaries: Refugee Camps, Civil War, and the Dilemmas of Humanitarian Aid (Ithaca, NY: Cornell University Press, 2005); Felix Gerdes, "Forced Migration and Armed Conflict: An Analytical Framework and a Case Study of Refugee-Warriors in Guinea," (Hamburg, Germany: Universitat Hamburg-IPW, Research Unit of Wars, Armament and Development, 2006).

7 Josephine Reynell, Political Pawns: Refugees in the Thai-Kampuchean Border (Oxford: Refugee Studies Program, University of Oxford, 1989); Liisa H. Malkki, "Refugees and Exile: From 'Refugee Studies' to the National Order of Things," Annual Review of Anthropology 24 (1995); Barbara Harrell-Bond, "Can Humanitarian Work with Refugees Be Humane?," Human Rights Quarterly 24 (2002); David Kennedy, The Dark Sides of Virtue: Reassessing International Humanitarianism (Princeton and Oxford: Princeton University Press, 2005); Ilana Feldman, "Difficult Distinctions: Refugee Law, Humanitarian Practice, and Political Identification in Gaza," Cultural Anthropology 22, no. 1 (2007); Kelly M. Greenhill, Weapons of Mass Migration: Forced Displacement, Coercion, and Foreign Policy (Ithaca, NY: Cornell University Press, 2010). 
due to the challenge of surveying such populations. This study takes a step toward filling that gap to assess the nature of activism among Syrian refugees in Jordan.

Even where agency is manifest, powerful forces structure violent and nonviolent processes alike. Scholars have analyzed the impacts of external military intervention on civil wars, ${ }^{8}$ and assessed how material support can further the goals of armed actors. ${ }^{9}$ What about unarmed actors? In peacetime contexts, resources have been thought to empower social movements. ${ }^{10}$ However, aid can also professionalize and even "tame" activism. ${ }^{11}$ In crises, "new humanitarianism" includes everything from emergency relief to conflict resolution, reconstruction, and transformations in social processes; ${ }^{12}$ this behemoth's impacts have mostly been grappled with only in theory. This study utilizes empirical insights to understand what transpires when both militarism and humanitarianism press upon mobilization among displaced people.

2 Methods

In six years of massive displacement from Syria, violence among refugees has been conspicuous in its absence: they have neither engaged in warfare from, nor spread it to, the countries hosting them on anything like the scale that security studies would predict. Most refugees' lives are characterized by the everyday of family life, economic struggle, social yearnings, and bureaucratic

8 Daniel Byman et al., Trends in Outside Support for Insurgent Movements (Santa Monica, CA: RAND, 2001); Michael G. Findley and Tze Kwang Teo, "Rethinking Third-Party Interventions into Civil Wars: An Actor-Centric Approach," The Journal of Politics 68, no. 4 (2006); David E. Cunningham, "Blocking Resolution: How External States Can Prolong Civil Wars," Journal of Peace Research 47, no. 2 (2010).

$9 \quad$ William Reno, Warlord Politics and African States (Boulder, Colorado: Lynne Reiner, 1998); Zachariah Cherian Mampilly, Rebel Rulers: Insurgent Governance and Civilian Life During Civil War (Ithaca, NY: Cornell University Press, 2011).

10 John D. McCarthy and Mayer N. Zald, "The Trend of Social Movements in America: Professionalization and Resource Mobilization," ed. General Learning Corporation (Morristown, NJ: General Learning Press, 1973).

11 Rema Hammami, "Ngos: The Professionalisation of Politics," Race \& Class 37, no. 2 (1995); Sheila Carapico, Political Aid and Arab Activism: Democracy Promotion, Justice, and Representation (New York: Cambridge University Press, 2014); Sarah Sunn Bush, The Taming of Democracy Assistance: Why Democracy Promotion Does Not Confront Dictators (Cambridge, U K: Cambridge University Press, 2015).

12 Mark Duffield, Global Governance and the New Wars (London and New York: Zed Books, 2001). 
structures. ${ }^{13}$ At the same time, many Syrians in Jordan are engaged in the very cause that led to their displacement: the uprising that turned into a critical conflict. Activism on behalf of this cause has evolved in the interstices of war's violent processes, ${ }^{14}$ but it continues to include humanitarian relief, media and journalism, fundraising, human rights advocacy, and other engagements that impact communities on both sides of the Syrian-Jordanian border. Few quantitative studies have ever captured such nonviolent behavior, if any at a micro level—with good reason: activists and refugees typify "hard-to-survey" populations.

Hard-to-survey populations may be hard to sample, identify, reach, persuade, or interview. ${ }^{15}$ Syrian activist refugees are at the intersection of several of these challenges. There is no sampling frame of their particular population and they are a fraction of the general refugee population; their behavior is informal and sometimes risky and therefore "hidden"; and they are part of a displaced (mobile) population that is more situated in urban areas than in bounded camp sites. Surveying activist refugees in Jordan demands an innovative tool. The one I chose for this study, used frequently in epidemiological research but not yet in political science, is a sampling and analysis method called respondent-driven sampling (RDS). ${ }^{16}$

RDS has been specifically developed for the study of hidden populations in a manner that approximates probability sampling. ${ }^{17} \mathrm{~A}$ network-based method, sampling begins with the non-random selection of "seeds" who recruit a limited number of their peers to participate, and the process repeats with each new wave of recruits, linked to each other through unique identification numbers. Crucially, an assessment of each respondent's social network size generates an estimate of her inclusion probability, which is used as a weight in the statistical analysis, allowing for population inference with estimates of uncertainty. My unique phone-based survey, conducted in 2016, gathered information from 176 activists in Amman who self-identified as having engaged in political, social,

\footnotetext{
13 Wendy Pearlman, "Culture or Bureaucracy? Challenges in Syrian refugees' initial settlement in Germany," Middle East Law and Governance 9, no. 3 (2017), pp. 313-327.

14 Stathis N. Kalyvas, The Logic of Violence in Civil War (New York: Cambrige University Press, 2006).

15 Roger Tourangeau, "Defining Hard-to-Survey Populations," in Hard-to-Survey Populations, ed. Roger Tourangeau, et al. (Cambridge, uk: Cambridge University Press, 2014).

16 RDS is predominantly used for biological surveillance of populations at high-risk for HIV infection, though it has lately been used in sociological studies of migrant populations.

17 Douglas D. Heckathorn, "Respondent-Driven Sampling: A New Approach to the Study of Hidden Populations," Social Problems 44, no. 2 (1997).
} 


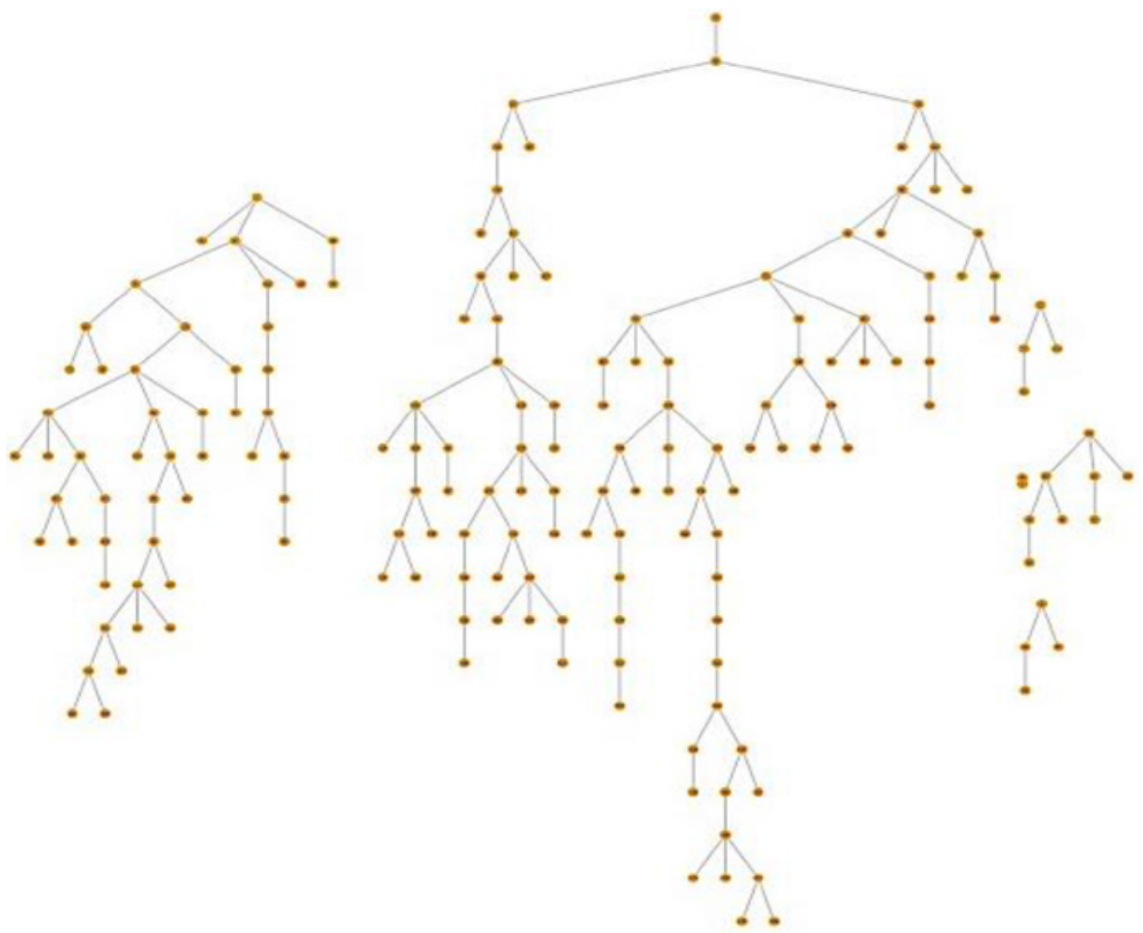

FIGURE 1 Eligible participants were 18 years or older, of Syrian origin living or working in Amman Governorate, had not previously engaged in the survey, and had engaged in activism on behalf of the Syrian cause since coming to Jordan

or economic activism (nashāt) on behalf of the Syrian cause (min ajli al-qadīya as-sūrīya). Figure 1 illustrates the recruitment process. ${ }^{18}$

Qualitative research, conducted in three stints from 2014 to 2016, enabled the identification and tracing of activism's nature and development, and engendered an appreciation of the humanitarian, military, organizational, and governmental context within which it is situated. While the survey systemized data about a large number of respondents, dozens of semi- and un-structured interviews with activists provided a fine-grained understanding of the routines, ambitions, and challenges of their engagements. Interviews with employees of inter- and non- governmental organizations (IGOs and NGOS) illuminated the

18 Traditionally, RDS surveys are conducted at study sites (usually equipped with blood testing laboratories) and recruitment proceeds through the physical passing of paper coupons. In contrast, I conducted it as a thirty-minute phone/Viber-based computerassisted interview; recruitment and appointments were coordinated through encrypted WhatsApp messages, and mobile top-ups were offered to participants as an incentive for survey completion. 
interests and imperatives that drive their response to the crisis, and their engagement of Syrians in it.

\section{$3 \quad$ Findings}

Syrian displacement to Jordan began in late 2011 and increased dramatically in 2013 as the Syrian conflict became characterized by brutal struggles for territorial control. The Jordanian government worked with the UN Refugee Agency (UNHCR), states, and numerous IGOS and international and local NGOs to respond to the humanitarian crisis in a manner that focuses aid on refugee and local communities. ${ }^{19}$ Through these crisis years, displaced Syrians in Jordan have persistently engaged in activism on behalf of the Syrian cause. In response to the survey, activists provided information about their demographic background in Syria, the nature of their activism in Jordan, their situation in a network of activists, and their future ambitions and political values. The survey systematizes our knowledge of who they are and what they do. Moreover, it reveals that activism has largely become part of the humanitarian response to the refugee crisis.

\section{Who are They?}

Syrian activists are generally a young and well-educated population. Inferring from my survey, over 70 percent of those in Amman are between the ages of 18 and 30 [95\% CI: 48, 95], and two-thirds are men [54, 79]. Nearly 95 percent have completed at least a secondary education, and nearly half have completed tertiary education. An overwhelming majority identified with the middle class when they lived in Syria [77, 94]; none identified as lower class.

\section{Where are They (From)?}

The activist population in Amman hails from across Syria, with the greatest concentrations coming from Dar'a Governorate (bordering Jordan) and Syria's most populated provinces. Outside of Amman (the survey's parameters), activists are also to be found in large numbers in Irbid City near the Syrian border. While Syrians in refugee camps have also engaged in contentious activity, ${ }^{20}$ the

19 Rawan Arar, "The New Grand Compromise: How Syrian Refugees Changed the Stakes in the Global Refugee Assistance Regime," Middle East Law and Governance 9, no. 3 (2017), pp. 298-312.

20 Killian Clarke, "Protest and Informal Leadership in Syrian Refugee Camps," in POMEPS Studies: Refugees and Migration Movements in the Middle East (Project on Middle East Political Science, 2017). 


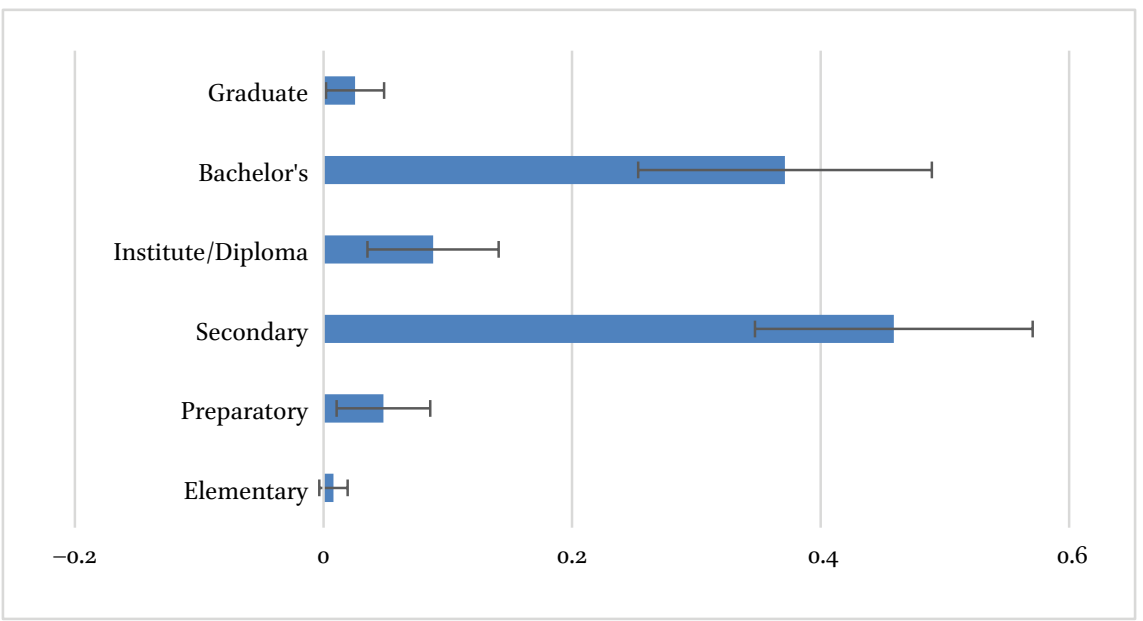

FIGURE 2 Education (proportions presented with 95\% confidence intervals)

\begin{tabular}{|c|c|c|}
\hline Place of origin & Registered refugees & Activist refugees \\
\hline Dar'a & $42 \%$ & $38 \%$ \\
\hline Homs & $16 \%$ & $20 \%$ \\
\hline Rural Damascus & $12 \%$ & $13 \%$ \\
\hline Aleppo & $10 \%$ & $7 \%$ \\
\hline Damascus & $7 \cdot 5 \%$ & $17 \%$ \\
\hline Other (9 provinces) & $0-5 \%$ & $0-5 \%$ \\
\hline
\end{tabular}

FIGURE 3 Place of origin of registered Syrian refugees in Jordan (Dec. 2016 figures from $\mathrm{UNHCR}$ ) and of activist refugees in Amman Governorate

structures of encampment likely mark off activism from its urban manifestations. As the founder of an initiative that sends aid to southern Syria observed: "If you want to have an impact, you have to be close to the capital."21

\section{What do They do?}

Prior to the Syrian uprising that began in 2011, only 20 percent of activist refugees had engaged in any form of activism [11, 31]. After the uprising began, nearly half of them did so before fleeing to Jordan. While these data suggest that many activists had mobilized previously, they also indicate that the crisis has opened distinct opportunities for engagement. ${ }^{22}$ The scope of their

2124 , interview by Rana B. Khoury, 25 August, 2015.

22 See Zeno, in this symposium, on how refugees negotiate their identities as positive contributors to society when given the chance. Basileus Zeno, "Dignity and Humiliation: 
activism since arriving has been wide, both in terms of type of activity and its target. The following are a selection of descriptions of each type of activism survey participants have been most recently and primarily engaged in:

Humanitarian Relief: "Finding and evaluating humanitarian cases, and putting them in touch with the appropriate parties that can provide assistance"

Advocacy: "I'm training in international law, regimes, governance, and leadership empowerment; we intend to work in institutions for civil awareness"

Development: "Working with adolescents, and serving on psychological counseling and empowerment projects for Jordanians and Syrians"

Media or Documentation: "I produce programs on the air that treat issues inside and outside of Syria"

Fundraising: "At the beginning of winter, we raise money from people for others in need and we purchase heaters and winter clothes for them"

Political Institution Building: "We support the local councils [opposition bodies in rebel-held Syria] with projects and workshops"

Political Party Activities: "I am a member of the political office and head of media and communications; we support a political resolution to the conflict in Syria"

Other: "I write poems about the suffering of the Syrian people and their martyrs. I publish it on Facebook and elsewhere; one poem received an award and was published in a book"

Unlike large social movements, activism does not hinge on mass participation. Nor is it understood here to include "one-off" events such as signing a petition. Rather, activism involves a moderate level of cooperation with actors who are primarily in the refugee host state, including other activists, NGOs, diplomats, and members of the host community. Three-quarters of activists are engaging on a volunteer basis $[64,86]$, reflecting legal constraints on refugees'

Identity Formation Among Syrian Refugees," Middle East Law and Governance 9, no. 3 (2017) pp. 282-297. 


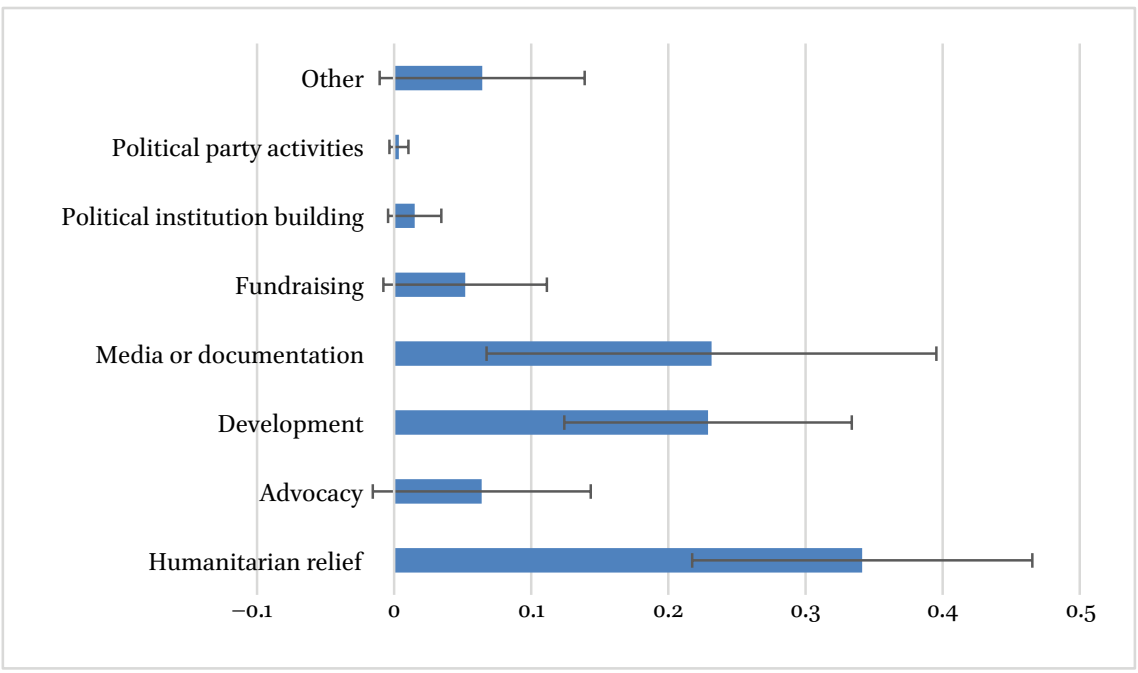

FIGURE 4 Form of activism that participants have been engaged in most recently

employment and the non-conventional nature of activism. Over 80 percent work with other Syrian activists [72, 93], who are mostly also in Jordan $[51,76]$, but over one-third of whom are in both Jordan and Syria or only in Syria.

\section{What don't They do (Anymore)?}

Over the course of their years in Jordan, Syrians have been engaged in more varied forms of activism than they were at the time of the survey in late 2016 . Past activism included more participation in political work, including political institution building, advocacy, and protests. Fundraising - a grassroots effort - also loses ground in a formal and expansive organizational landscape. In its most recent iteration, humanitarianism, development, and media account for fully $80 \%$ of activism. To date, more than sixty IG Os and NGOs have become partners with the UN in its Refugee and Resilience Response Plan in Jordan. Many of these partners are the organizations that two-thirds of Amman's activists are working with $[54,78]$, while just one-third are engaged with informal groups.

The survey also indicated that nearly 60 percent of participants believe that the number of activists in Jordan has been decreasing over the last few years $[49,70]$. It is not intuitive that the number of activists would decrease, even as the general refugee population increases. One clue to this puzzle is that those activists engaged in explicitly political work were unanimous in the perception that the number of activists has been decreasing. This view was corroborated to saturation in qualitative interviews; political activists explained that people 


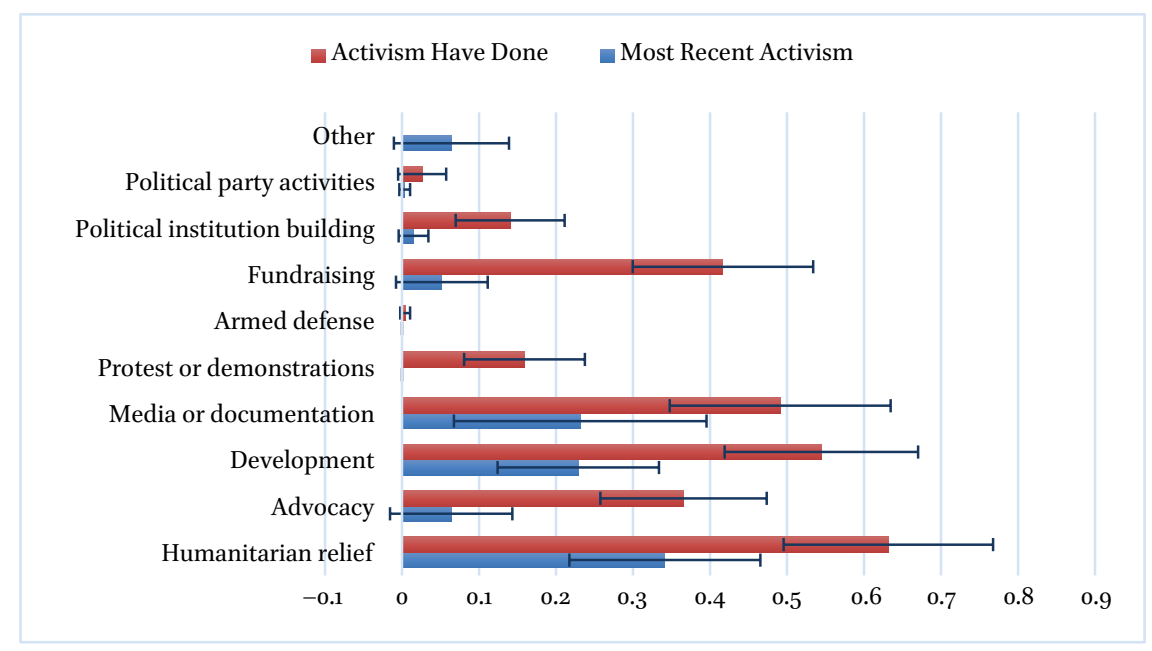

FIGURE 5 In red, the activism that participants have engaged in since coming to Jordan. In blue, the form of activism they have been engaged in most recently

were leaving Jordan: some migrated overseas, some went to Turkey where they perceived a more open political space, and others returned to rebel-held territory inside Syria.

\section{Qualitative Findings}

The trajectory of civilian mobilization began in Syria in 2011, when regular people faced their fears and took to the streets. ${ }^{23}$ In addition to protests, numerous informal initiatives emerged in advocacy, journalism, relief, and so forth. Before too long, similar efforts and new ones sprouted in Jordan among the growing Syrian refugee population there. To illustrate the trajectory of such initiatives, I describe developments in political and humanitarian realms.

The Syrian uprising transformed quickly into a conflict over the state and, early on, a large faction of the unarmed opposition coalesced around the notion of creating alternative political governance institutions for a post-Asad Syria. In turn, this project emerged among Syrians displaced from Dar'a to Jordan, who organized themselves into the Dar'a Governorate Council, DGC. Their kin in the Gulf-based diaspora created a body especially for coordinating assistance to these and other initiatives in and around Dar'a. Though the DGC was based (and thus tolerated) in Irbid, Jordan, its host government became wary of the group's Gulf sponsors due to their association with the Muslim Brothers. Jordan decided to foreclose the international meeting to elect the DGC's leadership;

23 Wendy Pearlman, "Narratives of Fear in Syria," Perspectives on Politics 14, no. 1 (2016). 
the 2013 election was held poolside at a hotel in Egypt, instead. In 2014, when enough territory had been captured by rebels in Dara, the DGC shuttered its Irbid operations and re-established itself inside. Affiliated bodies, like the Syrian Interim Government, did likewise over time. Though these institutions took root in Turkey, another major refugee host state, and inside Syria, they struggled to sustain financial support and political space in Jordan.

Widening our scope, we find that other actors in Jordan maneuver under a similar set of constraints. Western donor governments fund development organizations to assist local opposition institutions inside Syria, some of which are connected to the same Muslim Brothers-affiliated bodies. In turn, Jordan undertakes intensive vetting and selection of these organizations' Syrian field officers, recipient communities, and organizational partners. These processes so prolong programming that one such organization-which has supported upwards of ninety communities in northern Syria from its office in Turkeyhas managed to support just a handful in southern Syria from its office in Jordan. "In the North," one administrator of a Syrian organization tells me, "anything goes; in the South and with the borders here, it's humanitarian and civil."24 Yet humanitarians, too, are curbed. Early on, all relief was sent across the border through a pre-approved Jordanian contractor. Later, the process opened to just a couple of specially selected Syrian NGOs. Citing a lack of latitude, one Syrian NGO, specializing in education and psychosocial support projects in Dar'a, opened its headquarters in Turkey—despite the far distance from its beneficiaries. Those individuals and organizations that have remained in Jordan report that state security services are aware of and request information about their engagements.

Even so, the Jordanian government and its sense of security imperatives are not the sole factor shaping the space that has emerged for activity in the Syrian warscape. Aid, too, has shaped its contours significantly. Aid's impacts may be less intentional than those of a neighboring state government, but no less consequential.

In response to the Syrian crisis, a dense organizational landscape has developed in Jordan populated by IGOS, NGOs, and proactive Western embassies. This system for assistance emerged to grapple with enormous need, employing technical solutions to address a humanitarian emergency and providing developmental support for the longer-term, targeting both refugees and populations inside Syria. It is supplemented by more political projectscolloquially also called "development," but, more descriptively, "stabilization" 
or "non-humanitarian"-likewise carried out by NGOs (including for-profit companies) and funded by donor governments. The system's sheer size and resources are a stark contrast to some of the early grassroots initiatives that had emerged among Syrians in Jordan. Those initial local responses were ambitious humanitarian and political projects that were fueled by volunteers and a generous and politically invested diaspora. One such clinic in Irbid that served the displaced families of "martyrs" - rebels killed in battle-was shuttered in 2014, even as Médecins Sans Frontières, an ING O, was expanding its operations for refugees in the same area. Likewise, a housing project for martyr families that was sponsored by members of the Gulf diaspora proved unsustainable, at the same time that UNHCR and the World Food Program added to their rolls of beneficiaries. In the course of its expansion, the system has engaged and impacted Syrian activism—introducing financial imperatives and formalizing mobilization.

International organizations rely on Syrians for their networks and local knowledge. Activists are endowed with mètis, an ancient Greek term denoting "practical skills and acquired intelligence," 25 and so are well-positioned as "the interconnection between the donors and inside Syria," ${ }^{26}$ and between donors and the refugee community. To make use of it, NGOs often circumvent restrictions on Syrians' employment by providing them with generous travel stipends, for instance. These arrangements have evolved so that many activists who began as volunteers now receive remuneration. In 2014, a volunteer assisting martyr families derided other Syrians who were paid by organizations, saying they are "driven by politics and greed" and "diverted from attending the needs of civilians." In 2016, that same young man was gainfully employed by a Syrian NGO that is a local implementing partner for Western development organizations. ${ }^{27}$

As this organizational landscape has expanded, Syrians have been acquiring new technical skills in data collection, conducting needs assessments, grantwriting, and monitoring and evaluation operations. NGOs in the field offer training and certification programs, for instance in journalism and emergency response, creating a cadre that they can draw upon. Yet a tension commonly expressed by both Westerners and Syrians is the incongruence between the

\footnotetext{
25 James C. Scott, Seeing Like a State: How Certain Schemes to Improve the Human Condition Have Failed (New Haven: Yale University Press, 1998), p. 313.

2623 , interview by Rana B. Khoury, 1 August, 2015.

27 5a, interview by Rana B. Khoury, 4 August, 2014; 5b, interview by Rana B. Khoury, 2 September, 2016.
} 
former's practices and the latter's skillset. Young activists who blossomed in anti-government protests, or who were previously students or employees in unrelated fields, are not necessarily suited to be the technicians demanded for relief and service work. Similarly, larger western organizations and agencies note a conflict between their desire to work with local partners, and the associated risks of engaging inexperienced actors. Still, some savvy Syrian initiatives have thrived in this environment and have become the "go-to" partners for international organizations. Others have struggled to survive, unable to establish the right connections with donors or maintain sufficient funding. Many Syrians simply volunteer for local Jordanian religious and charitable associations providing aid to refugees, though they still identify as activists.

\section{Discussion}

The nature of activism among Syrians in Jordan has not been constant. As the violence in Syria has worsened, and the international humanitarian response in Jordan has swelled, activism has transformed from a grassroots response to an uprising into an aid-based response to a humanitarian crisis. This adaptation does not necessarily map onto the trajectory of each individual activist; certainly, there are early mobilizers who have moved on with their lives in Europe, and others who did not protest at all but who found their place in the scene that took shape in Jordan. Still, there appears to be a general process wherein activism is increasingly constricted to humanitarian endeavors.

Is this evolution attributable to external forces alone? To be sure, many Syrians chose to dedicate their energies to aid and service provision from the early days of the conflict. The violent escalation of hostilities inside Syria created a population in need of assistance, and many have believed, then and now, that they are fighting for their cause with the only weapons they are willing to hold. As one activist in Jordan declared of his humanitarian work in Syria: "I consider myself a resister, a fighter. There's more than one way to fight the regime."28

Certainly, similar imperatives existed in Jordan as the Syrian population swelled to hundreds of thousands of displaced people in need of relief. Yet, even there, revolutionary fervor was manifest for a time-in numerous protests held outside the Syrian Embassy in Amman, in the building of opposition governance institutions, and in the attempts of political actors to impact local endeavors. But opportunity structures are powerful and resources finite; 
security and humanitarian imperatives gave shape to an environment where Syrians could engage within certain bounds.

While the drivers of the Jordanian state have seemingly legible interests, those of the humanitarian system can be less clear. After all, it is an in-principle neutral and gigantic structure composed of numerous actors, organizations, norms, and institutions. But we need not read intent. The informal and formal "everyday elements" of intervention-social habits, bureaucratic procedures, approaches to data-impact these massive enterprises from the bottom up. ${ }^{29}$ In response to Syria, politics is displaced by "governance," rebels by "proscribed" versus "vetted" groups, constituents by "beneficiaries," survival by "stipends," and so on. Through discourse and ways of knowing the world, the system discerns technical problems to be resolved by technocrats, thereby "depoliticizing everything it touches." ${ }^{30}$ Indeed, the Syrian conflict is characterized by very little (productive) political or diplomatic intervention, but abundant military and humanitarian intervention. In this context-and perhaps because of itactivists are not fomenting mass mobilization to dismantle power structures; rather, they are responding to the war as a humanitarian crisis.

29 Séverine Autesserre, Peaceland: Conflict Resolution and the Everyday Politics of International Intervention (New York: Cambridge University Press, 2014).

3o James Ferguson, The Anti-Politics Machine: "Development," Depoliticization, and Bureaucratic Power in Lesotho (New York: Cambridge University Press, 1990). 